\title{
Potential Impacts of Water Stress on Rice Biomass Composition and Feedstock Availability for Bioenergy Production
}

\author{
Nurda Hussain ${ }^{1}$, Mukhtar Ahmed ${ }^{2}$ (D) Saowapa Duangpan ${ }^{3}$, Tajamul Hussain ${ }^{3}$ and Juntakan Taweekun ${ }^{4, *}$ \\ 1 Energy Technology Program, Faculty of Engineering, Prince of Songkla University, Hat Yai, \\ Songkhla 90112, Thailand; 6310120017@psu.ac.th \\ 2 Department of Agronomy, Faculty of Crop and Food Sciences, PMAS Arid Agriculture University, \\ Rawalpindi, Punjab 46300, Pakistan; ahmadmukhtar@uaar.edu.pk \\ 3 Agricultural Innovation and Management Division, Faculty of Natural Resources, \\ Prince of Songkla University, Hat Yai, Songkhla 90112, Thailand; saowapa.d@psu.ac.th (S.D.); \\ 6110630006@psu.ac.th (T.H.) \\ 4 Department of Mechanical and Mechatronics Engineering, Faculty of Engineering, \\ Prince of Songkla University, Hat Yai, Songkhla 90112, Thailand \\ * Correspondence: juntakan.t@psu.ac.th; Tel.: +66-896546846
}

Citation: Hussain, N.; Ahmed, M.; Duangpan, S.; Hussain, T.; Taweekun, J. Potential Impacts of Water Stress on Rice Biomass Composition and Feedstock Availability for Bioenergy Production. Sustainability 2021, 13, 10449. https://doi.org/10.3390/ su131810449

Academic Editor: Andrea Pezzuolo

Received: 11 August 2021

Accepted: 15 September 2021

Published: 19 September 2021

Publisher's Note: MDPI stays neutral with regard to jurisdictional claims in published maps and institutional affiliations.

Copyright: (c) 2021 by the authors. Licensee MDPI, Basel, Switzerland. This article is an open access article distributed under the terms and conditions of the Creative Commons Attribution (CC BY) license (https:// creativecommons.org/licenses/by/ $4.0 /)$.

\begin{abstract}
Bioenergy from rice biomass feedstock is considered one of the potential clean energy resources and several small biomass-based powerplants have been established in rice-growing areas of Thailand. Rice production is significantly affected by drought occurrence which results in declined biomass production and quality. The impact of water stress (WS) was evaluated on six rice cultivars for biomass quality, production and bioenergy potential. Rice cultivars were experimented on in the field under well-watered (WW) and WS conditions. Data for biomass contributing parameters were collected at harvest whereas rice biomass samples were analyzed for proximate and lignocellulosic contents. Results indicated that WS negatively influenced crop performance resulting in 11-41\% declined biomass yield (BY). Stability assessment indicated that cultivars Hom Pathum and Dum Ja were stress-tolerant as they exhibited smaller reductions by $11 \%$ in their BY under WS. Statistics for proximate components indicated a significant negative impact influencing biomass quality as ash contents of Hom Chan, Dum Ja and RD-15 were increased by $4-29 \%$. Lignocellulosic analysis indicated, an increase in lignin contents of Hom Nang Kaew, Hom Pathum, Dum Ja and RD-15 ranging 7-39\%. Reduced biomass production resulted in a $10-42 \%$ reduction in bioenergy potential (E). Results proved that cultivation of stress-susceptible cultivars or farmer's choice and occurrence of WS during crop growth will reduce biomass production, biomass feedstock availability to biomass-based powerplants and affect powerplant's conversion efficiency resulting in declined bioenergy production.
\end{abstract}

Keywords: rice; water stress; biomass feedstock availability; bioenergy potential

\section{Introduction}

Rice (Oryza sativa L.) is considered one of the main cereal crops in the world together with wheat and maize. Asia is a major rice-producing continent where rice is the main and cheap source of carbohydrates, protein, minerals and fiber along with the potential source of biomass feedstock for bioenergy. Moreover, agricultural production and energy resources are important for sustainable growth for the economy of any country to sustain economic growth. To reduce the impact of global warming and continued fuel and energy supplies, the use of renewable energy resources has become important [1]. Energy plants for bioenergy and biofuel production compete with food-producing species for land and water resources. According to Stone et al. [2], more land and water resources will be required to meet continuously increasing biofuel needs. In this scenario, crop residual biomass including rice straws and lignocellulosic biomass provides an alternative to this problem 
and can be converted to a number of products, i.e., biofuels [3]. Biomass is third and one of the largest energy resources worldwide [4] following coal and petroleum. These biomasses and residues are used in small powerplants as raw materials for energy generation [5]. Residues are carbon neutral which provides an advantage over fossil energy. For example, they can sequester $\mathrm{CO}_{2}$ during the growing period and release it to the environment during the combustion process resulting in zero net addition of $\mathrm{CO}_{2}$ [6]. However, most residues and rice biomass including straws and husk are burnt in farming areas due to a lack of appropriate collection from fields after grain harvest which results in energy loss and causes environmental and health concerns [7]. Presently, governments worldwide have planned and established strategic attention to practice renewable energy resources in structuring their national energy policies. In Thailand, efforts are made to restructure the national energy plan by increasing the share of renewable energy technologies. Biofuels, heat and electricity have been obtained continually through renewable energy and the agricultural residues are major source for heat production in Thailand [8]. According to Thailand's Alternative Energy Development Plan of 2015, Thailand had set a goal to increase the share of renewable energy to $30 \%$ in total energy consumption by 2036 which is almost 39,388 ktoe of energy [9]. AEDP's main objective is to promote renewable energy at the country's full capability. Approximately 16.40-58.28 million tons of rice biomass, which includes rice straw and husk, were estimated which contributed a major portion of available wastes from field crops. In a recent study, the bioenergy potential of rice biomass has been estimated at $807,845 \mathrm{TJ}$ in seven regions of Thailand [10]. To achieve the goals of the national plan for renewable and bioenergy, a number of small biomass-based powerplants have been established in major rice-growing areas of Thailand. In these powerplants, rice biomass is used to generate electricity in Thailand and its contribution was as a second most important resource [11].

Water stress (WS) is an important factor that affects biomass production. WS leads to a decline in production and furthermore, a continuous reduced biomass production can potentially influence the biomass feedstock availability for bioenergy production [2]. WS occurs due to seasonal variations in rainfall in the current scenario of climate change. WS or drought occurrence is a serious threat to crop production for grain and biomass feedstock availability worldwide including Thailand. According to the Office of Agricultural Economics, Thailand [12], rainfed lowland rice is a major component of the rice production system of Thailand with a 9-million-hectare area. Terminal drought and WS occurrence are common in Thailand when the rice crop is at the reproductive stages and thus the crop fails to produce optimum yields [13]. Water is important during all crop growth stages, but reproductive stages are critical when, if WS occurs, a higher reduction in quantity as well as quality will be caused. According to Venuprasad et al. [14], the rice crop is extremely sensitive and vulnerable if WS occurs at reproductive growth stages. WS alters the plant biomass composition, causes substantial biomass yield (BY) losses and reduces the quality of products depending upon duration and intensity of stress. Biomass, in terms of energy, can yield three major final products including energy for heating purposes, fuel for transport and raw material for certain chemicals [15]. Energy characteristics comprise proximate components including moisture contents (MC), volatile matter (VM), fixed carbon (FC) and ash contents while characteristics of ultimate analysis include elemental composition for carbon, nitrogen, hydrogen, sulfur and higher heating value (HHV) [16]. Proximate and ultimate components are an important part of biomass as the concentration of these components affects biomass quality for devolatilization, power generation and energy output. Higher MC and ash contents affect biomass quality as well as decrease the energy conversion efficiency and energy output; therefore, low MC and ash along with high VM are desired. HHV is also an important component that yields maximum energy output. Straw biomasses are completely composed of cell walls and lignified carbohydrates, and structural proteins and minerals are present in these cell walls [17]. Lignocellulosic properties (cellulose, hemicellulose, and lignin) are important characteristics of biomass, and energy conversion and pyrolysis processes are affected by the behavior and concentration 
of these components [18]. The concentration of these components usually ranges from 32 to $47 \%$ for cellulose, 19 to $27 \%$ for hemicellulose and 5 to $24 \%$ for lignin $[19,20]$. Cellulose and hemicellulose are tightly packed layers due to the outer layer of lignin. Generally, cellulose and hemicellulose are major components in straws. In the biochemical conversion process, it is necessary to pretreat the rice biomass so that the lignin protective layer is decomposed and cellulose, as well as hemicellulose, is available to start chemical and enzyme activity. Lignin is usually converted slowly at $160-900{ }^{\circ} \mathrm{C}$, while cellulose and hemicellulose are decomposed rapidly at $220-315^{\circ} \mathrm{C}$ and $315-400{ }^{\circ} \mathrm{C}$, respectively [21]. This indicates that the presence of higher lignin contents in biomass will make the process more complex which requires higher energy input for decomposition thus increasing the conversion cost. WS affects the biomass composition for energy contents, thus influencing the conversion efficiency. According to Al-Hakimi et al. [22], cellulose, lignin, and pectin's concentration was potentially decreased whereas the concentration of hemicellulose was increased in soybean's shoots when grown under WS.

Continuous and viable biomass feedstock supply is necessary for biofuel production [23]; however, WS occurrence impacts the quality and BY. According to Emerson et al. [23], it is crucial to investigate the impact of WS on crop production and quantification of impacts of WS on crop production is a vital element for analyzing the biomass feedstock availability. Neglecting this quantification and BY estimation by cultivar and impact of WS on production will result in reduced biomass feedstock availability to established powerplants which will not only influence overall energy potential (E) but also influence the input cost of energy conversion process due to changes occurred in biomass composition. Cultivar type, the physiological response of a specific cultivar and the conditions of the growing environment also influence biomass composition and BY. Stable and stress-tolerant cultivars with the higher capability to adapt WS are recommended to be cultivated to minimize the crop production risks [24] in this scenario. This is because stress-tolerant cultivars exhibit a relatively stable and higher yield response under a diverse range of environments [25]. Approximately 116 cultivars have been reported under cultivation in different rice-growing areas of Thailand [26]. These cultivars vary in terms of their production potential and physiological characteristics. Farmers in Thailand choose to grow specific cultivars of their choice as they are concerned with the economic part of the plant. Preference for plantation of specific cultivars changes due to production level differences over years. To satisfy local farmer's requirements, it is important to obtain information on cultivar production performance, by cultivar type, growing site and growing conditions including sensitivity to WS. Biomass utilization systems [27] and small biomass-based powerplants need precise biomass feedstock data and a prediction of variability and availability of biomass feedstock for their designing in a specific area. Hence, it becomes important to understand that how WS can impact biomass composition, biomass feedstock availability and may pose a potential threat to established small biomass-based powerplants for sustainable energy generation. Some studies have been conducted for BY estimation for the establishment of biomass-based powerplants, but the authors do not give attention to the cultivar types for their biomass producing potential difference under WW and WS conditions, changes predicted due to farmers choice over time and cultivar failure under WS. Therefore, this study was conducted to determine the impact of WS on the rice biomass productivity, quality, cultivar stability and E of the rice biomass feedstock of Thai lowland rice cultivars. As per the authors' knowledge, this is the first study to investigate the potential impacts of WS and cultivar types on rice biomass composition, quality and biomass feedstock availability to established small biomass-based powerplants.

\section{Materials and Methods}

\subsection{Data Collection}

Six commonly available Thai lowland rice cultivars based on popularity among farmers including Hom Nang Kaew (1), Hom Chan (2), Hom Pathum (3), Dum Ja (4), Khao Dawk Mali-105 (5) and RD-15 (6) were assessed in the current study. Data for stem height 
(SH), stem numbers (SN) and BY were collected from assessment trials conducted in the field research area $\left(7^{\circ} 00^{\prime} 14.5^{\prime \prime} \mathrm{N}, 100^{\circ} 30^{\prime} 14.7^{\prime \prime} \mathrm{E}\right)$ of Faculty of Natural Resources, Prince of Songkla University, Hat Yai, Songkhla Province, in Southern Thailand (Figure 1) during 2019-2020. Songkhla province is located in the eastern part of Southern Thailand and the climate of Songkhla is characterized by hot or dry season and rainy season. Mean minimum and mean maximum temperature reaches $24.8^{\circ} \mathrm{C}$ and $31.5^{\circ} \mathrm{C}$, respectively, with an annual average temperature of $27.9^{\circ} \mathrm{C}$ and average annual rainfall of $20166.7 \mathrm{~mm}$ [28]. In brief, trials were conducted using a randomized complete block design with three replicates and two treatments including well-watered treatment (WWT) and water-stressed treatment (WST). Plants in WWT received supplementary irrigation throughout the growing period including rainfall; however, plants in WST received only rainfall as irrigation water after tillering stage. Each cultivar was grown in a separate plot with 4 rows of 3-m length. Plants were maintained at $25 \mathrm{~cm}$ while rows were distanced at $30 \mathrm{~cm}$. Number of days to $50 \%$ maturity (DM) was recorded by counting the number of days from the planting date. $\mathrm{SH}, \mathrm{SN}$ and BY were recorded at harvest by randomly selecting three plants for each cultivar from each treatment plot. Plant biomass samples were dried in an oven at $70{ }^{\circ} \mathrm{C}$ for different time durations until a constant weight was observed to obtain BY on a dry weight basis.

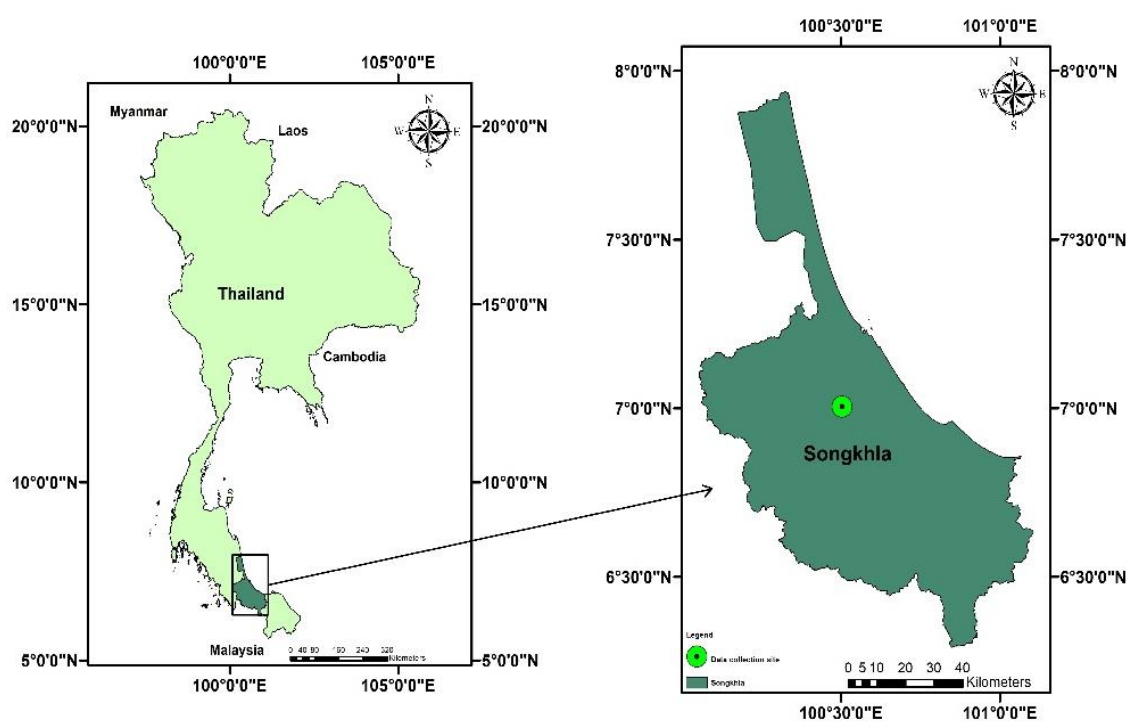

Figure 1. Experimental location in Southern Thailand (Source: Adapted from ArcGIS).

\subsection{Biomass Composition Analysis}

Oven-dried plant biomass samples were finely ground into $1 \mathrm{~mm}$ (grinder model: Retch Cyclone Mill Twister). The ground biomass samples were stored in sealed plastic bags until biomass composition analysis was performed. Biomass composition analysis was performed for proximate contents using a macro thermogravimetric analyzer (model: TGA 701, LECO, USA) at Scientific Equipment Center of Prince of Songkla University, Thailand to examine MC, VM, FC and ash contents. Lignocellulosic analysis was performed by analyzing acid detergent fiber (ADF), neutral detergent fiber (NDF) and acid detergent lignin (ADL) which were used to compute percentages of cellulose contents (1), hemicellulose contents (2), lignin contents (3) and extractives (4) by following equations. HHV (5) was computed using formulae given by Lozano-García and Parras-Alcántara [29]. Energy conversion [30] for potential energy per hectare area in kilowatt-hour unit (kWh.ha $\left.{ }^{-1}\right)$ was computed to obtain E by Equation (6) in which C1 is coefficient (3.6 MJ) of conversion of MJ to $\mathrm{kWH}$ and C2 is plant conversion efficiency taken as the average of $20 \%$ [31].

$$
\text { Cellulose contents }=\mathrm{ADF}-\mathrm{ADL}
$$




$$
\begin{gathered}
\text { Hemicellulose content }=\mathrm{NDF}-\mathrm{ADF} \\
\text { Lignin content }=\mathrm{ADL} \\
\text { Extractives }=100-(\text { Cellulose }+ \text { Hemicellulose }+ \text { Lignin }) \\
\mathrm{HHV}=0.3536 \mathrm{FC}+0.1559 \mathrm{VM}-0.0078 \mathrm{~A} \\
\mathrm{E}=(\mathrm{HHV} / \mathrm{C} 1) \times \mathrm{C} 2 \times \text { Biomass } \\
\mathrm{SSI}=(1-\mathrm{Ys} / \mathrm{Yw}) / \mathrm{D}
\end{gathered}
$$

\subsection{Statistical Analysis}

Crop data and biomass composition analysis data obtained from experiment and laboratory, respectively, were used separately in statistical program $\mathrm{R}$ (version: 2.14.0) to test the significance. A two-way analysis of variance (ANOVA) was performed for DM, SH, SN and BY from three replications with effect to treatments. Mean comparisons were made by using the least significant difference (LSD) and $p$-value $<0.05$ was considered as significantly different. ANOVA was also performed for biomass composition elements to assess the significance of results and the effect of treatments on biomass composition. Pearson's correlation analysis was conducted for evaluated biomass contributing parameters and energy components. To analyze the stability of rice cultivars for BY, mean BY was used to calculate the measure of biomass production stability and stress susceptibility index (SSI) (7) was computed [32]. Mean relative yield (RY) for comparison under WS was determined as the yield of each cultivar grown in WST divided by the yield of the highest yielded cultivar among six assessed cultivars.

\section{Results}

\subsection{Rice Productivity}

There was a highly significant alteration for DM, SH, SN and BY, whereas no significant difference was observed for interactions among cultivars and treatments for BY (Table 1). DM was increased under WS for all cultivars (Figure 2a) and the difference ranged 4-11 days. SH at maturity (Figure $2 \mathrm{~b}$ ) and SN per meter square (Figure 2c) were decreased for all cultivars under WS. SH was decreased by 3-25\% under WS for tested cultivars. SN.m ${ }^{-2}$ decreased $2-89 \%$ in WST. Biomass (Figure 2d) was reduced by $11-41 \%$ in WST. SSI (Table 2) values ranged 0.51-1.97 under WS, whereas RY for biomass under WW, (RYWW) and WS (RYWS) ranged from 0.24 to 1.00 and 0.16 to 1.00 , respectively (Table 2). SSI for BY indicated that cultivars 3 and 4 exhibited comparatively smaller reductions in their BY and were found to be stress-tolerant and high-yielding for biomass production.

Table 1. Mean squares of analysis of variance for days to maturity, stem height, stem numbers and biomass yield of six lowland rice cultivars.

\begin{tabular}{cccccc}
\hline SOV & df & Days to Maturity & Stem Height & Stem Number & Biomass Yield \\
\hline Replications & 2 & 5.44 & 69.75 & $917.33^{* * *}$ & 0.77 \\
Cultivars & 5 & $2224.18^{* * *}$ & $7699.20^{* * *}$ & $1996.47^{* * *}$ & $205.00^{* * *}$ \\
Treatments & 1 & $498.78^{* * *}$ & $5088.44^{* * *}$ & $9604.00^{* * *}$ & $59.75^{* * *}$ \\
Cultivars $\times$ & 5 & $14.44^{* * *}$ & $356.11^{* * *}$ & $2347.93^{* * *}$ & $2.05^{\mathrm{ns}}$ \\
Treatments & 22 & 2.23 & 78.02 & 215.24 & 2.06 \\
Error & 1.04 & 6.42 & 9.67 & 12.88 \\
\hline CV $\%$ & & 1.04 & \\
\hline
\end{tabular}

$\mathrm{SOV}=$ source of variation, $\mathrm{df}=$ degree of freedom, ${ }^{* * *}=$ highly significant $(p<0.001)$, ns $=$ non-significant. 

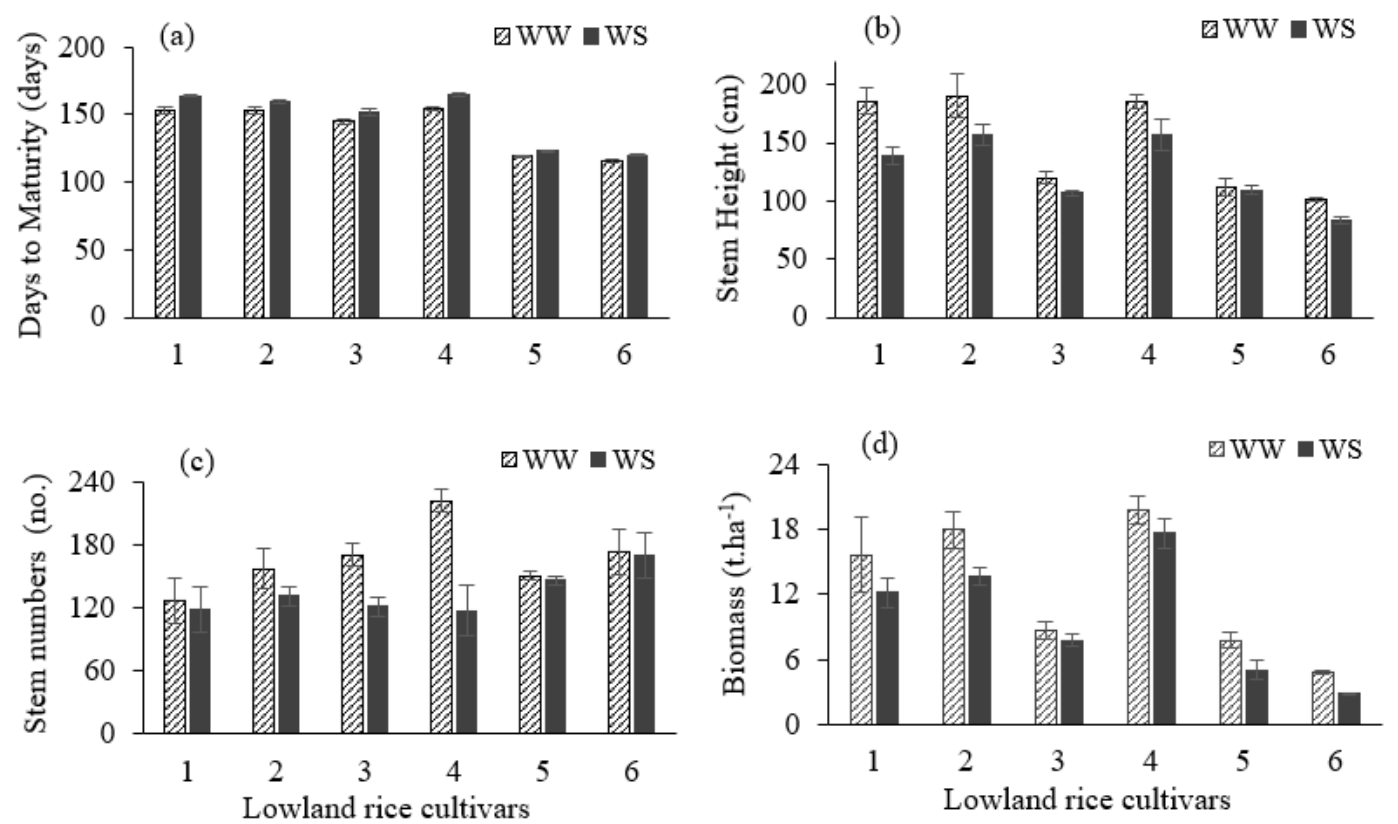

Figure 2. Days to maturity (a), stem height (b), stem numbers (c) and biomass yield (d) for six lowland rice cultivars under well-watered (WW) and water-stressed (WS) conditions. Vertical bars refer to \pm standard errors for average data from three replicates.

Table 2. Stress susceptibility index (SSI) and relative yield (RY) for biomass yield in six lowland rice cultivars.

\begin{tabular}{lcccccc}
\hline & \multirow{2}{*}{ Cultivars } & \multicolumn{2}{c}{ Well-Watered } & \multicolumn{2}{c}{ Water-Stressed } \\
\cline { 3 - 6 } & & BY \pm SE & RYWW & BY \pm SE & SSI & RYWS \\
\hline 1 & Hom Nang Kaew & $15.66 \pm 1.99$ & 0.79 & $12.18 \pm 0.81$ & 1.07 & 0.69 \\
2 & Hom Chan & $17.96 \pm 0.99$ & 0.91 & $13.70 \pm 0.48$ & 1.14 & 0.78 \\
3 & Hom Pathum & $8.70 \pm 0.44$ & 0.44 & $7.75 \pm 0.31$ & 0.53 & 0.51 \\
4 & Dum Ja & $19.72 \pm 0.74$ & 1.00 & $17.61 \pm 0.81$ & 1.68 & 1.97 \\
5 & Khao Dawk Mali-105 & $7.76 \pm 0.41$ & 0.39 & $5.05 \pm 0.52$ & 0.29 \\
6 & RD-15 & $4.81 \pm 0.08$ & 0.24 & $2.84 \pm 0.05$ & 1.97 & -16 \\
\hline
\end{tabular}

$\mathrm{BY}=$ mean biomass yield $\pm \mathrm{SE}$ = standard error, $\mathrm{SSI}$ = stress susceptibility index; $\mathrm{RYW}$ = relative yield under well - watered conditions; RYWS $=$ relative yield under water - stressed conditions .

\subsection{Biomass Composition and Energy Contents}

Statistical comparisons for proximate contents (Table 3) indicated a highly significant difference among MC, VM, FC, ash, HHV and E for cultivars, treatments as well as their interactions except for a non-significant difference for VM under treatment and for FC under cultivar as well as the interaction of cultivar and treatments. MC (Figure 3a) were higher for cultivars $1,2,3,4$ and 5 by $5,2,14,4$ and $3 \%$, whereas they were decreased for cultivar 6 by $4 \%$, respectively, when compared with WST in proximate analysis. VM (Figure $3 b$ ) was increased for cultivars 1 and 3 by $2 \%$ whereas decreased for cultivars 4 and 6 by $2 \%$, however no change was observed for cultivars 2 and 5 . Composition analysis indicated that FC contents were between 15 and $16 \%$ and values ranged between 15.52-16.00 for WWT and 15.14-15.69 for WST, respectively. FC contents (Figure 3c) were increased for cultivar 1 by $1 \%$ whereas they were decreased for cultivars 3,4 and 6 by 3 , 4 and $5 \%$, respectively, and no change was observed for cultivars 2 and 5 . Ash contents (Figure 3d) were increased for cultivars 2, 4 and 6 by 4,22 and 29\%, whereas they were decreased for cultivars 1,3 and 5 by 15,17 and $4 \%$, respectively. HHV was increased for cultivars 1 and 3 by $2 \%$, whereas it was decreased for cultivars 4 and 6 by 2 and 3\%, respectively, whereas no significant change was observed for cultivars 2 and 5 . 
Table 3. Mean squares of analysis of variance of proximate analysis, HHV and potential bioenergy $€$ for six lowland rice cultivars.

\begin{tabular}{|c|c|c|c|c|c|c|c|}
\hline SOV & df & MC & VM & FC & Ash & HHV & E \\
\hline $\mathrm{R}$ & 2 & 0.011 & 0.037 & 0.062 & 0.001 & 0.001 & 331007 \\
\hline $\mathrm{C}$ & 5 & $0.965^{* * *}$ & $5.524^{* * *}$ & $0.119^{\mathrm{ns}}$ & $5.200 * * *$ & $0.149^{* * *}$ & $84120000^{* * *}$ \\
\hline $\mathrm{T}$ & 1 & $0.528^{* * *}$ & $0.139^{\mathrm{ns}}$ & $0.686^{*}$ & $0.232 * * *$ & $0.008^{* *}$ & $24310000^{* * * *}$ \\
\hline $\mathrm{C} \times \mathrm{T}$ & 5 & $0.206^{* * *}$ & $1.455^{* * *}$ & $0.157^{\mathrm{ns}}$ & $3.444^{* * *}$ & $0.046^{* * *}$ & $834913^{\mathrm{ns}}$ \\
\hline Error & 22 & 0.001 & 0.139 & 0.121 & 0.006 & 0.002 & 818514 \\
\hline $\mathrm{CV} \%$ & & 0.57 & 0.54 & 2.23 & 0.98 & 0.41 & 12.82 \\
\hline
\end{tabular}

$\mathrm{SOV}=$ source of variation, $\mathrm{df}=$ degree of freedom, $\mathrm{R}=$ replications, $\mathrm{C}=$ cultivars, $\mathrm{T}=$ treatments, $\mathrm{MC}=$ moisture contents, $\mathrm{VM}=$ volatile matter, FC $=$ fixed carbon, HHV $=$ higher heating value, $\mathrm{E}=$ Potential bioenergy, ${ }^{* * *}=$ highly significant $(p<0.001)$, ${ }^{* *}=$ moderately significant $(p<0.01),{ }^{*}=$ significant $(p<0.05), \mathrm{ns}=$ non-significant.
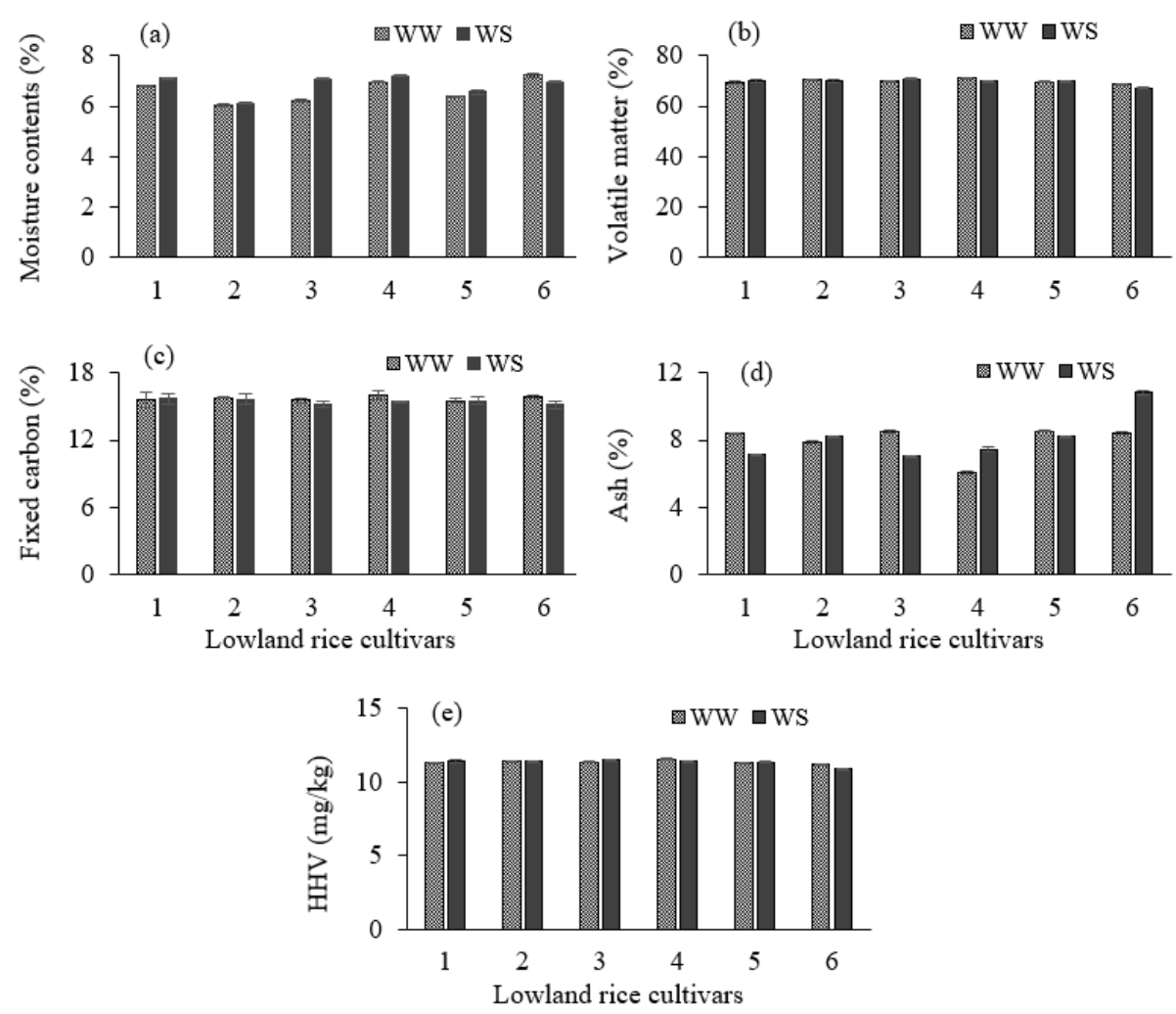

Figure 3. Proximate contents including moisture contents (a), volatile matter (b), fixed carbon contents (c) ash contents (d) and higher heating value (e) for six lowland rice cultivars in well-watered (WW) and water-stressed (WS) conditions. Vertical bars refer to \pm standard errors for average data from three replicates.

\subsection{Impact of WS on Lignocellulosic Properties}

There was a highly significant difference (Table 4) for cellulose, hemicellulose, lignin and extractives for cultivars, treatments and their interactions and a non-significant difference for hemicellulose under treatments. Cellulose contents (Figure 4a) were increased for cultivars 1,3 and 6 by 4,16 and 3\%, whereas they were decreased for cultivars 2 and 5 by 4 and 1\%, respectively, whereas no change was observed for cultivar 4 under WS. Hemicellulose contents (Figure $4 \mathrm{~b}$ ) were increased for cultivars 1, 2, and 3 by 3, 6 and $10 \%$ whereas they were decreased for cultivars 4,5 and 6 by 1,3 and $12 \%$, respectively, under WS. Lignin contents (Figure 4c) were increased for cultivars 1, 3, 4 and 6 by 9, 39, 9 and $7 \%$, whereas they were decreased for cultivars 2 and 5 by 2 and $3 \%$, respectively, under WS. Extractives (Figure 4d) were increased for cultivars 5 and 6 by 3 and $7 \%$, whereas 
they were decreased for cultivars 1,2 and 3 by 5,1 and $21 \%$, respectively, whereas no change was observed for cultivar 4 under WS.

Table 4. Mean squares of analysis of variance of lignocellulosic analysis of six lowland rice cultivars.

\begin{tabular}{cccccc}
\hline SOV & df & Cellulose & Hemicellulose & Lignin & Extractives \\
\hline $\mathrm{R}$ & 2 & $0.012^{* * *}$ & 0.016 & 0.006 & 0.003 \\
$\mathrm{C}$ & 5 & $5.606^{* * *}$ & $6.562^{* * *}$ & $0.039^{* * *}$ & $16.708^{* * *}$ \\
$\mathrm{~T}$ & 1 & $7.471^{* * *}$ & $0.043^{\mathrm{ns}}$ & $0.777^{* * *}$ & $14.618^{* * *}$ \\
$\mathrm{C} \times \mathrm{T}$ & 5 & $6.304^{* * *}$ & $6.733^{* * *}$ & $0.300^{* * *}$ & $22.527^{* * *}$ \\
Error & 22 & 0.050 & 0.052 & 0.002 & $0.002^{2}$ \\
\hline CV \% & & 0.730 & 0.860 & 1.360 & 0.220 \\
\hline
\end{tabular}

SOV = source of variation, $\mathrm{df}=$ degree of freedom, $\mathrm{R}=$ replications, $\mathrm{C}=$ cultivars, $\mathrm{T}=$ treatments, $\mathrm{CV}=$ coefficient of variation, ${ }^{* * *}=$ highly significant $(p<0.001), \mathrm{ns}=$ non-significant.
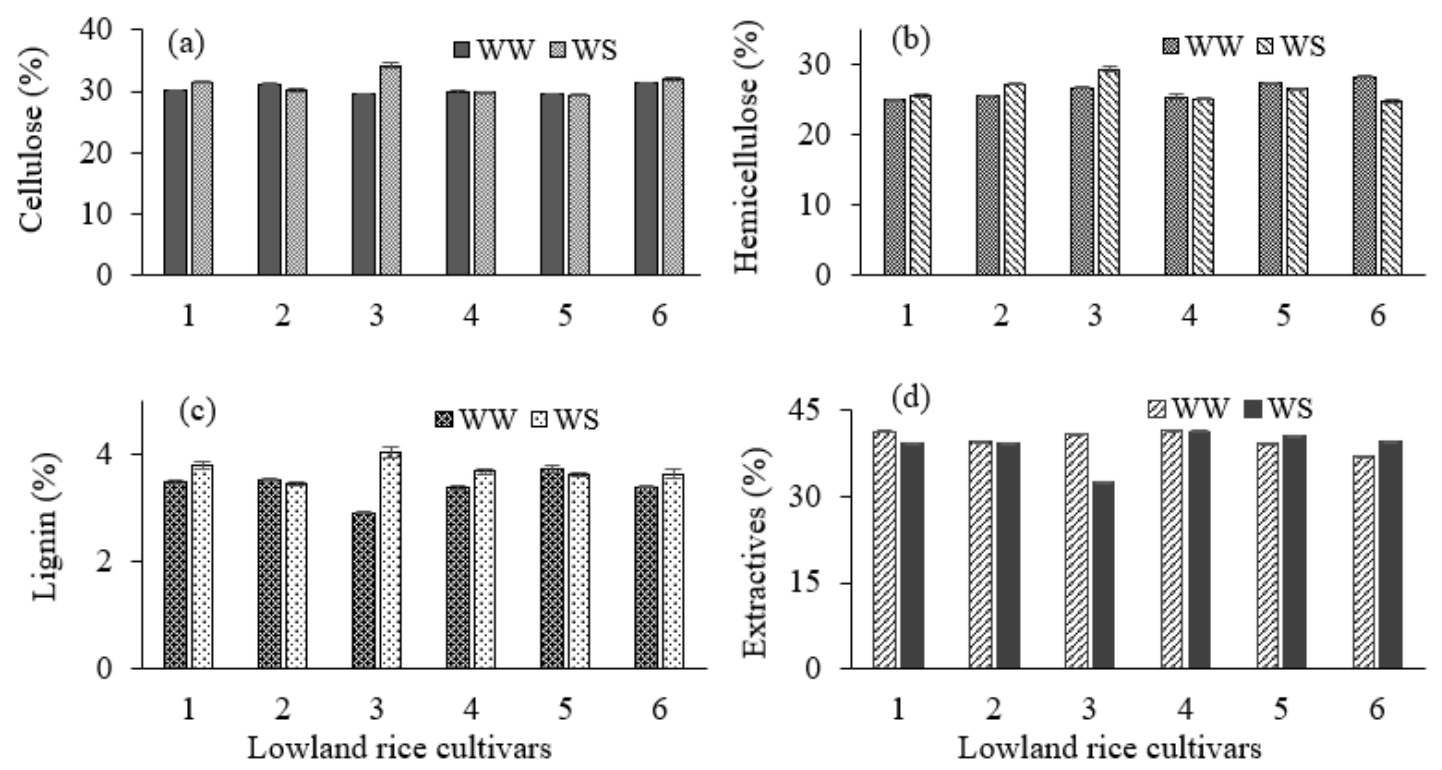

Figure 4. Cellulose (a), Hemicellulose (b), Lignin (c) and Extractives (d) percentages for six lowland rice cultivars in well-watered (WW) and water-stressed (WS) conditions. Vertical bars refer to \pm standard errors for average data from three replicates.

\subsection{Energy Potential (E)}

E, which depends upon HHV as well as biomass production and composition, was significantly different (Table 3 ) due to the effect of cultivar type and water treatments except by the interaction between the cultivar type and treatments for all cultivars evaluated. All cultivars exhibited a higher potential for bioenergy under WW conditions (Figure 5). Values ranged between 2990 and 12,685 kWh.ha ${ }^{-1}$ for WWT and 1724 and 11,142 kWh.ha ${ }^{-1}$ for WST, respectively (Figure 5). Maximum bioenergy potential was achieved by cultivar 6 due to higher biomass production. E was reduced under WS for all cultivars including cultivar 1, 2, 3, 4, 5 and 6 by 21\%, 24\%, 10\%, 12\%, 35\% and $42 \%$, respectively (Figure 5). 


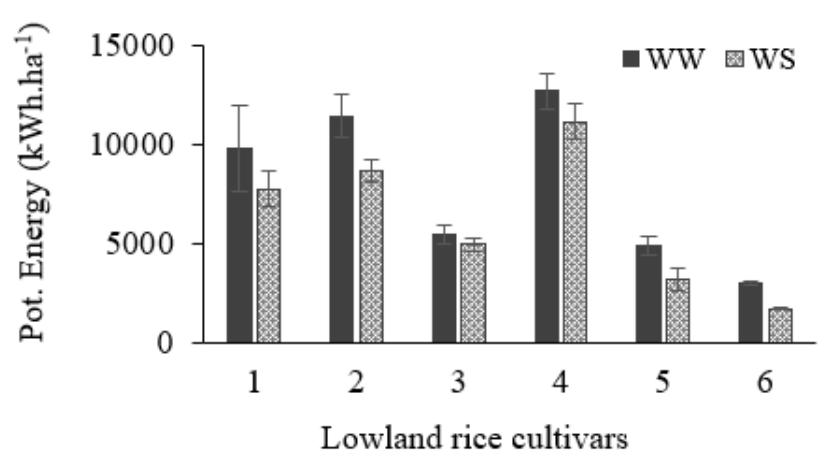

Figure 5. Potential bioenergy per hectare from biomass of lowland rice cultivars in well-watered (WW) and water-stressed (WS) conditions. Vertical bars refer to \pm standard errors for average data from three replicates.

\subsection{Correlation Study}

SN were significantly $(p<0.05)$ negative, whereas SH and BY were highly significant $(p<0.001)$ and positively correlated with DM (Table S1). SH was also highly significant $(p<0.001)$ and positively associated with BY (Table S1).

Correlation for proximate components indicated a highly significant $(p<0.001)$ positive association among HHV, BY, E and VM, whereas a highly significant $(p<0.001)$ negative association was observed between ash contents and VM (Table S2). Significant $(p<0.05)$ positive correlation among BY, E and FC was observed, whereas a significantly $(p<0.05)$ negative association among ash contents and FC was observed (Table S2). Ash contents were highly significant $(p<0.001)$ and negatively correlated with HHV, BY and E (Table S2). Highly significant $(p<0.001)$ and positive association was observed among BY, HHV and E (Table S2).

Correlation analysis for lignocellulosic properties resulted in a highly significant $(p<0.001)$ positive association among cellulose hemicellulose and lignin contents (Table S3), whereas cellulose, hemicellulose and lignin were significantly $(p<0.001)$ negatively correlated (Table S3).

\section{Discussion}

WS affected biomass production performance of all cultivars. Maturity duration was delayed under WS. SH and SN was decreased for all cultivars under WS. Davatgar et al. [33] and Hussain et al. [34] observed that WS caused a significant decline in SH of rice cultivars. SH was negatively correlated with WS. Reduction in SH occurs as the reduced water supply under WS limits the cell elongation which results in a reduction in internode length [35]. Higher SH and more SN contributed to an increase in plant biomass. Furthermore, SH had a significant positive correlation with BY. Knoll et al. [36] also observed that mature SH was highly correlated with biomass yield. Reduction in $\mathrm{SH}$ and SN under WS resulted in a reduction in plant biomass. Zain et al. [37] reported that GY, biomass, filled spikelet, and SH were reduced under the increased duration of WS intervals. Increased WS also decreased the plant morphology and rice yield production in a study conducted by Zulkarnain et al. [38]. Cultivars 3 and 4 exhibited comparatively smaller reductions in their BY maintaining plant performance under WS which exhibited their stress tolerance capability. Bruckner and Frohberg [39] stated that cultivars with low SSI values, (less than 1) could be considered stress-tolerant cultivars as they showed comparatively smaller reductions in yield under WS conditions when compared with WW. RY was taken into consideration as RY gives the measure of relatively lower or higher yield under WS conditions. Cultivars 3 and 4 were found to be stress-tolerant as well as relatively high yielding for biomass production. Bouman and Tuong [40] also stated that tolerant cultivars maintained their yields as they maintained higher plant physiological processes and recovery of plant functions following WS. Hence, it was observed that cultivation 
of stress-tolerant, as well as high-yielding cultivars, will sustain the biomass feedstock availability rather than stress-susceptible cultivars.

The proximate composition of biomass of all cultivars was altered. According to Obernberger and Thek [41], MC may vary significantly, and it is an undesired component of any type of fuel. MC also influence the heating values, combustion temperatures as well as combustion efficiencies. Higher MC in biomass release lower net heating values; therefore, low $\mathrm{MC}$ are desired in biomass for energy applications. Results indicated that MC were increased when biomass samples were used from WST resulting in a negative impact on biomass quality. VM is a desired component in biomass and according to Demirbas [42] and Vassilev et al. [43], and it usually comprises $\mathrm{CO}, \mathrm{CO}_{2}, \mathrm{H}_{2}, \mathrm{MC}$, and tars. Depending upon raw materials, generally, biomass contains higher VM ranging from $75 \%$ to $90 \%$ [44]. VM was found to have a significant positive correlation with HHV, BY and E while having a significant correlation with ash. Higher ash contents resulted in lower VM. Kreil and Broekema [45] stated that in a combustion system, FC produces char and it is burnt as a solid substance and higher FC results in a positive impact on the combustion process. According to Yang et al. [46], FC contents should be expected at the range $7-20 \%$. In this study, composition analysis indicated that FC contents were between 15 and $16 \%$. FC was negatively correlated with ash whereas it was in positive correlation with BY and E. Ash is considered as incombustible matter in biomass, which is not only an undesirable material, but also higher ash contents result in high carbon and gas emissions. Ash was negatively correlated with HHV, BY and E. Another important factor is "Slag" formation in boilers or furnaces during the combustion process which results because of the lower melting point of ash in thermal processing. Hodgson et al. stated that slag formation in boilers or furnaces hinders the energy conversion and combustion efficiency is decreased [47]. Results indicated that although cultivars 2 and 4 were stress-tolerant and maintained their BY, their biomass quality was affected as ash contents were increased, which is an undesired attribute. Results exhibited that cultivation of such cultivars over time or due to farmer's preference and occurrence of WS will not only impact biomass quantity but will also impact the biomass quality. An increase in ash contents of specific cultivars under WS indicted that biomass obtained from these cultivars will produce more ash, limiting the combustion efficiency. Heating values are considered as energy contents of fuel as standard which is usually described as lower heating value or HHV. HHV was positively correlated with VM while negatively correlated with ash. Voca et al. [48] found that there was no significant difference observed for the HHV of Plum and it is possible that different cultivars may exhibit similar HHV. Heating values also depend upon the concentration of FC, VM and ash. According to Shrivastava et al. [49] biomass containing higher FC, VM and low ash contents will deliver higher heating values. Cultivar 2, 4 and 6 indicated that ash contents were increased while remaining proximate properties were decreased under WS. This indicated that WS influenced the biomass development and proximate composition which ultimately influenced heating values. Results supported the hypothesis that biomass obtained from cultivation of such types of cultivars over time and WS may influence the heating potential of rice biomass.

WS caused the variations in lignocellulosic response for all cultivars. During the energy conversion process, higher levels of cellulose and hemicellulose and low levels of lignin and extractives are desired. We found that WS increased the levels of lignin and extractives for cultivars 1, 3, 4 and 6 whereas it decreased cultivars 2 and 5. Although cellulose for cultivar 6 and cellulose and hemicellulose for cultivars 1 and 3 were increased, it is a point of concern that an increase in lignin contents will require higher energy input during the energy conversion process. Cultivar 4 maintained the concentration of cellulose and hemicellulose under WS despite the increase in lignin and extractives. Cultivars with higher cellulose and hemicellulose concentration in their biomass will be able to exhibit higher energy potential. Palamanit et al. [50] found that during pyrolysis, the biomass with higher levels of cellulose as well as hemicellulose contents promoted comparatively greater yields of bio-oil and liquid than the biomass with higher lignin contents. It is due 
to this reason that thermal disintegration and conversion of cellulose and hemicellulose is much easier than lignin. Kim et al. [51] also stated that biomass containing higher cellulose and hemicellulose contents produced higher bio-oil yield. The current results indicated that an increase in lignin contents of biomass produced under WS will impact the quality of energy output. In addition, it could be that the reduction in hemicellulose of cultivar 6 may not affect energy output as cellulose concentration was increased. This is similar to Qu et al. [52], who also found that cellulose provided a high bio-oil yield during pyrolysis because cellulose is comparatively more volatile as compared to hemicellulose. However, cellulose and hemicellulose alone cannot predict and constitute the energy output from a specific area grown as the concentration of these components is computed with the produced biomass.

Energy potential (E) is dependent upon $\mathrm{HHV}, \mathrm{BY}$ and biomass composition. Higher E was achieved under WW conditions by all cultivars, and it was significantly reduced under WS conditions (Figure 5). E was also positively correlated with FC, VM, HHV and BY, whereas it was negatively associated with ash contents (Table S2). The results indicated that higher biomass-producing cultivars would generate higher $\mathrm{E}$ and reduction in biomass yield will negatively impact the energy potential. Maximum E was achieved by cultivar 6 due to higher biomass production. Ambrosio et al. [30] also found that higher bioenergy potential was associated with higher biomass production and HHV. Biomass productivity is dependent upon crop growing conditions, planting density, fertilizer and nutrient availability, crop management practices and climatic factors which can limit biomass production. In a crop management study, it was observed that the heating value and the potential for energy for power generation from maize crop along with dry matter productivity and grain production was increased by nitrogen fertilizer application while it was slightly influenced by inter-row spacing [30]. Cultivation of low-biomass-producing cultivars over time, or by farmer choice for grains, will also negatively impact biomass availability to biomass-based powerplants. In this study, although some cultivars, e.g., cultivar 4, exhibited smaller reductions in BY under WS and rice fields grown with such cultivars will be able to contribute higher bioenergy, the results indicated the potential decline in biomass feedstock availability, biomass quality and overall energy output if WS or drought occurs during the growing season.

\section{Conclusions}

This study revealed that WS resulted in a negative impact on all cultivars' performance affecting the biomass composition, and hence the quality, and biomass feedstock availability. Cultivars Hom Pathum and Dum Ja were found to be stress-tolerant as they exhibited smaller reductions in their BY under WS indicating that cultivation of stress-tolerant cultivars will help to stabilize BY and feedstock availability as compared to susceptible cultivars. The proximate composition of biomass of all cultivars was altered and the quality of biomass of cultivars Hom Chan, Dum Ja and RD-15 was lowered due to an increase in ash contents. Lignin and extractives which are undesired in higher concentrations were also increased under WS for most cultivars. E, which is dependent upon HHV and biomass production potential, was decreased $10-42 \%$ under WS. It was concluded that E will be affected if low biomass-yielding, stress-susceptible cultivars are grown, WS occurs, or farmers continue to grow specific cultivars. In such a case, biomass availability will be reduced to established small biomass-based power plants along with lowered biomass quality, resulting in a decline in final energy potential.

Supplementary Materials: The following are available online at https:/ / www.mdpi.com/article/ 10.3390/su131810449/s1, Table S1: Combined Pearson's correlation coefficients matrix for days to maturity, stem height, stem numbers and biomass yield, Table S2: Combined Pearson's correlation coefficients matrix for moisture contents (MC), volatile matter (VM), fixed carbon (FC), ash, higher heating value (HHV), biomass yield (BY) and energy potential (E), Table S3: Combined Pearson's correlation coefficients matrix for lignocellulosic components. 
Author Contributions: N.H. conceived and conceptualized the idea. N.H. and T.H. performed the literature review. M.A. and S.D. provided technical expertise to strengthen the basic idea. T.H. helped in the collection of data and its analysis. J.T., acquired funds, proofread and provided intellectual guidance along with M.A. and S.D. All authors read the first draft, helped in revision and approved the article. All authors have read and agreed to the published version of the manuscript.

Funding: This research was partially funded by Faculty of Engineering, Prince of Songkla University and Graduate School, Prince of Songkla University with Graduate School thesis research funding for topics on community problem solving.

Acknowledgments: Authors are thankful to anonymous reviewers for providing valuable comments. We would like to thank Sobia Ikram, researcher, School of Medical and Applied Sciences, Central Queensland University, Australia for her help in R program.

Conflicts of Interest: The authors declare no conflict of interest.

\section{References}

1. Cuiping, L.; Yanyongjie; Chuangzhi, W.; Haitao, H. Study on the distribution and quantity of biomass residues resource in China. Biomass Bioenergy 2004, 27, 111-117. [CrossRef]

2. Stone, K.C.; Hunt, P.G.; Cantrell, K.B.; Ro, K.S. The potential impacts of biomass feedstock production on water resource availability. Bioresour. Technol. 2010, 101, 2014-2025. [CrossRef] [PubMed]

3. Suzane, T.; Regina, D.; Savioli, M.; Maria, S.; Garcia, R. Sugarcane straw as a potential second generation feedstock for biorefinery and white biotechnology applications. Biomass Bioenergy 2021, 144, 105896. [CrossRef]

4. Hashem, M.; Ali, E.H.; Abdel-Basset, R. Recycling rice straw into Biofuel "ethanol” by Saccharomyces cerevisiae and Pichia guilliermondii. J. Agric. Sci. Technol. 2013, 15, 709-721.

5. Varvel, G.E.; Wilhelm, W.W. Cob Biomass Production in the Western Corn Belt. BioEnergy Res. 2008, 1, 223-228. [CrossRef]

6. Healy, M.; Toupin, K. Biofuel Conversion-First Step-Fuel Selection. In Proceedings of the Clearwater Clean Coal Conference, Clearwater, FL, USA, 6-10 June 2010.

7. Lim, J.S.; Manan, Z.A.; Alwi, S.R.W.; Hashim, H. A review on utilisation of biomass from rice industry as a source of renewable energy. Renew. Sustain. Energy Rev. 2012, 16, 3084-3094. [CrossRef]

8. Cheewaphongphan, P.; Junpen, A.; Kamnoet, O.; Garivait, S. Study on the potential of rice straws as a supplementary fuel in very small power plants in Thailand. Energies 2018, 11, 270. [CrossRef]

9. Alternative Energy and Efficiency Information Center. Thailand Alternative Energy Situation; Alternative Energy and Efficiency Information Center, Department of Alternative Energy Development and Efficiency, Ministry of Energy: Bangkok, Thailand, 2015; pp. 1-57.

10. Wang, W.; Porninta, K.; Aggarangsi, P.; Leksawasdi, N.; Li, L.; Chen, X.; Zhuang, X.; Yuan, Z.; Qi, W. Bioenergy development in Thailand based on the potential estimation from crop residues and livestock manures. Biomass Bioenergy 2021, 144, 105914. [CrossRef]

11. Barz, M.; Delivand, M.K. Agricultural Residues as Promising Biofuels for Biomass Power Generation in Thailand. J. Sustain. Energy Environ. Spec. Issue 2011, 21-27.

12. Office of Agricultural Economics (OAE). Agricultural Statistics of Thailand; Ministry of Agriculture and Cooperatives: Bangkok, Thailand, 2016; p. 206.

13. Monkham, T.; Jongdee, B.; Pantuwan, G.; Mitchell, J.H.; Sanitchon, J.; Fukai, S. 517 Responses of rainfed lowland rice genotypes to terminal drought in Northeast Thailand. Khon Kaen Agric. J. 2016, 44, 517-526.

14. Venuprasad, R.; Lafitte, H.R.; Atlin, G.N. Response to direct selection for grain yield under drought stress in rice. Crop Sci. 2007, 47, 285-293. [CrossRef]

15. Saxena, R.C.; Adhikari, D.K.; Goyal, H.B. Biomass-based energy fuel through biochemical routes: A review. Renew. Sustain. Energy Rev. 2009, 13, 167-178. [CrossRef]

16. Imam, T.; Capareda, S. Characterization of bio-oil, syn-gas and biochar from switchgrass pyrolysis at various temperatures. J. Anal. Appl. Pyrolysis. 2012, 93, 170-177. [CrossRef]

17. Antongiovanni, M.; Sargentini, C. Variability in chemical composition of straws. Option Méditérranéennes 1991, 16, 49-53.

18. van de Velden, M.; Baeyens, J.; Brems, A.; Janssens, B.; Dewil, R. Fundamentals, kinetics and endothermicity of the biomass pyrolysis reaction. Renew. Energy 2010, 35, 232-242. [CrossRef]

19. Garrote, G.; Domínguez, H.; Parajó, J.C. Autohydrolysis of corncob: Study of non-isothermal operation for xylooligosaccharide production. J. Food Eng. 2002, 52, 211-218. [CrossRef]

20. Saha, B.C. Hemicellulose bioconversion. J. Ind. Microbiol. Biotechnol. 2003, 30, 279-291. [CrossRef]

21. Yang, H.; Yan, R.; Chen, H.; Lee, D.H.; Zheng, C. Characteristics of hemicellulose, cellulose and lignin pyrolysis. Fuel 2007, 86, 1781-1788. [CrossRef]

22. Al-Hakimi, A.M.A. Counteraction of drought stress on soybean plants by seed soaking in salicylic acid. Int. J. Bot. 2006, 2, 421-426. [CrossRef] 
23. Emerson, R.; Hoover, A.; Ray, A.; Lacey, J.; Cortez, M.; Payne, C.; Karlen, D.; Birrell, S.; Laird, D.; Kallenbach, R.; et al. Drought effects on composition and yield for corn stover, mixed grasses, and Miscanthus as bioenergy feedstocks. Biofuels 2014, 5, 275-291. [CrossRef]

24. Manickavelu, A.; Nadarajan, N.; Ganesh, S.K.; Gnanamalar, R.P.; Babu, R.C. Drought tolerance in rice: Morphological and molecular genetic consideration. Plant Growth Regul. 2006, 50, 121-138. [CrossRef]

25. Anantha, M.S.; Patel, D.; Quintana, M.; Swain, P.; Dwivedi, J.L.; Torres, R.O.; Verulkar, S.B.; Variar, M.; Mandal, N.P.; Kumar, A.; et al. Trait combinations that improve rice yield under drought: Sahbhagi Dhan and new drought-tolerant varieties in South Asia. Crop Sci. 2016, 56, 408-421. [CrossRef]

26. Rice Department-Ministry of Agriculture and Cooperatives. Rice Knowledge Bank: Rice Cultivate Species. Available online: http: / / www.ricethailand.go.th/Rkb/varieties /index.php-file=content.php\&id=1.htm (accessed on 8 January 2017).

27. Summers, M.D.; Jenkins, B.M.; Hyde, P.R.; Williams, J.F.; Mutters, R.G.; Scardacci, S.C.; Hair, M.W. Biomass production and allocation in rice with implications for straw harvesting and utilization. Biomass Bioenergy 2003, 24, 163-173. [CrossRef]

28. TMD. Climatological Center, Thai Meteorological Department Report. 2021. Available online: http://climate.tmd.go.th/ (accessed on 19 August 2021).

29. Lozano-García, B.; Parras-Alcántara, L. Short-term effects of olive mill by-products on soil organic carbon, total N, C: N ratio and stratification ratios in a Mediterranean olive grove. Agric. Ecosyst. Environ. 2013, 165, 68-73. [CrossRef]

30. Ambrosio, R.; Pauletti, V.; Barth, G.; Povh, F.P.; da Silva, D.A.; Blum, H. Energy potential of residual maize biomass at different spacings and nitrogen doses. Ciência Agrotecnologia 2017, 41, 626-633. [CrossRef]

31. Nogueira, L.A.H.; Lora, E.E.S. Dendroenergia: Fundamentos e Aplicações, 2nd ed.; Interciência: Rio de Janeiro, Brazil, $2003 ;$ p. 200.

32. Fischer, R.A.; Maurer, R. Drought resistance in spring wheat cultivars. I. Grain yield responses. Aust. J. Agric. Res. 1978, 29, 897-912. [CrossRef]

33. Davatgar, N.; Neishabouri, M.R.; Sepaskhah, A.R.; Soltani, A. Physiological and morphological responses of rice (Oryza sativa L.) to varying water stress management strategies. Int. J. Plant Prod. 2009, 3, 19-32. [CrossRef]

34. Hussain, T.; Anothai, J.; Nualsri, C.; Soonsuwon, W. Application of CSM-CERES-Rice in scheduling irrigation and simulating effect of drought stress on upland rice yield. Indian J. Agric. Res. 2018, 52, 140-145. [CrossRef]

35. Patel, D.P.; Das, A.; Munda, G.C.; Ghosh, P.K.; Bordoloi, J.S.; Kumar, M. Evaluation of yield and physiological attributes of high-yielding rice varieties under aerobic and flood-irrigated management practices in mid-hills ecosystem. Agric. Water Manag. 2010, 97, 1269-1276. [CrossRef]

36. Knoll, J.E.; Anderson, W.F.; Missaoui, A.; Hale, A.; Hanna, W.W. Biomass production and stability of five energycane cultivars at two latitudes in Georgia. Agrosyst. Geosci. Environ. 2021, 4, 1-14. [CrossRef]

37. Zain, N.A.M.; Ismail, M.R.; Puteh, A.; Mahmood, M.; Islam, M.R. Impact of cyclic water stress on growth, physiological responses and yield of rice (Oryza sativa L.) grown in tropical environment. Ciência Rural. 2014, 44, 2136-2141. [CrossRef]

38. Zulkarnain, W.M.; Ismail, M.R.; Ashrafuzzaman, M.; Saud, H.M.; Haroun, I.C. Rice growth and yield under rain shelter house as influenced by different water regimes. Int. J. Agric. Biol. 2009, 11, 566-570.

39. Bruckner, P.L.; Frohberg, R.C. Stress Tolerance and Adaptation in Spring Wheat 1. Crop Sci. 1987, 27, 31-36. [CrossRef]

40. Tuong, T.P.; Bouman, B.A.M. Field water mangement to save water and increase its productivity in irrigated lowland rice. Agric. Water Manag. 2000, 1615, 1-20.

41. Obernberger, I.; Thek, G. Physical characterisation and chemical composition of densified biomass fuels with regard to their combustion behavior. Biomass Bioenergy 2004, 27, 653-669. [CrossRef]

42. Demirbas, A. Combustion characteristics of different biomass fuels. Prog. Energy Combust. Sci. 2004, 30, 219-230. [CrossRef]

43. Vassilev, S.V.; Baxter, D.; Andersen, L.K.; Vassileva, C.G. An overview of the chemical composition of biomass. Fuel 2010, 89, 913-933. [CrossRef]

44. Khan, A.A.; de Jong, W.; Jansens, P.J.; Spliethoff, H. Biomass combustion in fluidized bed boilers: Potential problems and remedies. Fuel Process. Technol. 2009, 90, 21-50. [CrossRef]

45. Kreil, K.; Broekema, S. Chemical and Heat Value Characterization of Perennial Herbaceous Biomass Mixtures; Analysis Report; Microbeam Technologies: Grand Forks, ND, USA, 2010.

46. Yang, Y.B.; Ryu, C.; Khor, A.; Yates, N.E.; Sharifi, V.N.; Swithenbank, J. Effect of fuel properties on biomass combustion. Part II. Modelling approach-Identification of the controlling factors. Fuel 2005, 84, 2116-2130. [CrossRef]

47. Hodgson, E.M.; Fahmi, R.; Yates, N.; Barraclough, T.; Shield, I.; Allison, G.; Bridgwater, A.V.; Donnison, I.S. Miscanthus as a feedstock for fast-pyrolysis: Does agronomic treatment affect quality? Bioresour. Technol. 2010, 101, 6185-6191. [CrossRef]

48. Voća, N.; Bilandžija, N.; Jurišić, V.; Matin, A.; Krička, T.; Sedak, I. Proximate, ultimate, and energy values analysis of plum biomass by-products case study: Croatia's potential. J. Agric. Sci. Technol. 2016, 18, 1655-1666.

49. Shrivastava, P.; Kumar, A.; Tekasakul, P.; Lam, S.S.; Palamanit, A. Comparative investigation of yield and quality of bio-oil and biochar from pyrolysis of woody and non-woody biomasses. Energies 2021, 14, 1092. [CrossRef]

50. Palamanit, A.; Khongphakdi, P.; Tirawanichakul, Y.; Phusunti, N. Investigation of yields and qualities of pyrolysis products obtained from oil palm biomass using an agitated bed pyrolysis reactor. Biofuel Res. J. 2019, 6, 1065-1079. [CrossRef]

51. Kim, S.S.; Ly, H.V.; Kim, J.; Choi, J.H.; Woo, H.C. Thermogravimetric characteristics and pyrolysis kinetics of Alga Sagarssum sp. biomass. Bioresour. Technol. 2013, 139, 242-248. [CrossRef]

52. Qu, X.; Liang, P.; Wang, Z.; Zhang, R.; Sun, D.; Gong, X.; Gan, Z.; Bi, J. Pilot Development of Polygeneration Process of Circulating Fluidized Bed Combustion combined with Coal Pyrolysis. Chem. Eng. Technol. 2011, 34, 61-68. [CrossRef] 